\title{
Onomatology of the Term Patela: From Ancient Greece to America
}

\author{
Onomatología del Término Patela: Desde la Antigua Grecia hasta América
}

\author{
Jorge Eduardo Duque Parra ${ }^{1,2}$; John Barco Ríos ${ }^{1}$ \& Carlos Eduardo Castaño Molina1
}

DUQUE, P. J. E.; BARCO, R. J. \& CASTAÑO, M. C. E. Onomatology of the term patela: From ancient Greece to America. Int. J. Morphol., 36(2):758-761, 2018.

SUMMARY: The purpose of this study was to conduct a historical analysis of the terms "patella" and "rotula" according to its onomatology to name the sesamoid bone in the anterior region of the knee and to determine whether it corresponds to international anatomical terminology use. For the study, 46 well-conditioned sesamoid bones were selected. They were measured by using a digital gauge to determine their geometric shape and then compare these with the given meanings throughout history. Results show that the dimensions obtained from these sesamoid bones do not correspond to a thumbwheel shape (rotula), instead they correspond to a dished shape (patella). This coincides with the term used in the current Terminologia Anatomica. The patella term to name the sesamoid bone in the anterior region of the knee is the most appropriate and accepted term in international anatomical terminology.

KEY WORDS: History; Patella; Terminology.

\section{INTRODUCTION}

Anatomy is one of the most important basic sciences in all schools of medical education (Davis et al., 2014). This discipline has its own language, the Terminologia Anatomica, by means of which the different corporal components can be accurately described and understood in the same way by all the readers (Grelsamer, 2005) worldwide. This also facilitated communication within the scientific community (Duque Parra et al., 2002).

It is presumed that the study of anatomy is as ancient as man himself, which perhaps arose from the curiosity of the first settlers, when they examined the open wounds of their congeners and the interiors of those animals that hunted for their subsistence. (Duque Parra et al., 2012). In the present study, we observed the existence of some body structures, whose shape, location and anatomical relationships were similar to those seen in other living beings. The names those structures were given, were recognized and orally transmitted to the next generations, long before the invention of writing. It is presumed that this prehistoric knowledge was lost in time.

With the invention of some form of writing during the bronze age, approximately at the end of the fourth millennium $\mathrm{BC}$, man begins to leave his impressions imprinted on small clay chips (Schmandt-Besserat, 2002). These later evolved into tablets of clay, slightly larger, on which information was recorded (Rudgley, 2000). Apparently, writing arose initially because of man's need to express what his eyes saw, doing so through pictograms (Yule, 2007). That is to say, through the representation of figures of animals and objects without any connection. Later, this type of writing was developed into a slightly more complex form, with the creation of ideograms, resulting from the combination of pictograms (Yule), with which man could now express ideas and concepts through geometric symbols. However, there are no records of the exact moment in which man begins recording his knowledge about the human body, or the names that different structures were given, by this type, or any other type of writing.

Just as the first attempts at writing began in Sumer, it is likely that this also occurred in pre-Columbian America, long before the arrival of the first Europeans in America. Indigenous communities of that time, especially the Maya, Aztecs and Incas, had already established a system of writing, which for some was pictographic, while

\footnotetext{
${ }^{1}$ Departamento de Ciencias Básicas. Programa de Medicina. Universidad de Caldas, Manizales, Colombia.

${ }^{2}$ Programa de Medicina,Universidad de Manizales, Manizales, Colombia.
} 
others considered it a complete phonological system (Cardona, 1994). Through this type of pre-Columbian writing the natives left their ancestral knowledge, including possibly some kind of anatomical knowledge. However, with the arrival of the conquistadors, especially the Spaniards, characterized by their greed, plundering and abuse (Fernández de Oviedo, 1996), these communities, their culture (De las Casas, 1985) and their ancestral knowledge were destroyed. In time, much of the language and terms used by the different indigenous communities were also lost. This also became apparent, with the arrival of the first Spanish physicians in the 16th century, particularly in Colombia, accompanied by barbers (surgeons) and bleeders (Amezcua Martínez, 1997). The medical and anatomical language used at that time, by these empirical "professionals" becomes evident when in 1790, bleeder Juan Garcia bandaged a patient who had fractured the knee bone, which they called a kneecap or shock (Cortés-García, 2010), but in the International Anatomical Terminology is called patella and appears with the reference A02.5.05.001 (FIPAT, 1998).

\section{MATERIAL AND METHOD}

A descriptive study was carried out to determine the geometric shape of the sesamoid bones of the anterior region of the knee. For this purpose, we selected 46 of these bones that were in good condition, belonging to the osteotheque of the Universidad de Caldas, and Universidad de Manizales. They were measured with a digital caliper to determine the dimensions in terms of their length and width, to determine whether the morphometric measurement of this sesamoid bone is more akin to a wheel (rotula) or to a plate (patella). We noted that while studying the bone material, we adhered strictly to the medical legal criteria in the decree 786 of 1990. Furthermore, all principles of the Helsinki declaration for medical research were taken into account, guaranteeing respectful treatment of the parts obtained in the study, and in order to maintain the deceased person's dignity and integrity, their data was kept confidential.

\section{RESULTS}

From the 46 sesamoid bones assessed, their width was determined to be between $34.05 \mathrm{~mm}$ and $50.96 \mathrm{~mm}$, with an average value of $42.39 \mathrm{~mm}$. While the length of the bones ranges from $31.38 \mathrm{~mm}$ to $48.02 \mathrm{~mm}$, with an average value of $40.25 \mathrm{~mm}$. The average values obtained for the width and length of these bones are more or less similar, which allows their semicircular shape to stand out, with the exception of its lower border where the apex is located, thus discarding from this the wheel shape. This bone has two faces, one anterior slightly convex, and one posterior slightly concave, showing a geometric figure that resembles more to a saucer or defense shield.

\section{DISCUSSION}

Although Hippocrates, by the fourth century BC, uses the term epimulis (Gersh, 2012) to refer to the knee, it does not refer at all to the sesamoid bone of that region. At the time of the conquest of the Americas, two names were used for this bone, "choque" and "rótula" (Cortés-García). The term "choque" links with "choquezuela", which involves the suffix -uelo, which is very restricted as a diminutive in medieval Castilian (García-Jáuregui, 2009), but is currently accepted in medical language, as can be seen when reviewing several Spanish-language dictionaries (Mascaró y Porcar, 1983) and Spanish dictionaries (Castell, 1985; García-Pelayo y Gross, 1993), as a synonym for the rotula culture (GarcíaJáuregui, 2006), which incorporated the anatomist Ioan Valverde de Amufco in his book titled "History of the Compounding of the Human Body", 1556 (Valverde de Amufco, 1556). This name was preserved by Spanish physicians and incorporated into knowledge derived from the conquest (De Toro y Gisbert, 1968), which originates from the word "chueca", which refers to a rounded bone or part of it, and which fits into the hollow of another bone, which was used for anatomical formations such as the rotula (Garcia-Jauregui).

The term rótula has been assimilated by the Spaniards and is already recognized in contemporary texts of anatomy, written or translated by them from the original in English (García-Porrero y Hurlé, 2005; Schünke et al., 2011; Moore et al., 2013), denoting their ignorance or little interest in accepting what is established in the international anatomical terminology. The foregoing indicates that Spanish anatomists and translators do not give the task of consulting the original language which the anatomical terms come from: Latin. The term rotula is the diminutive of wheel (CadavidRestrepo, 1942), that is to say wheel (Cruveilhier, 1851; Moliner, 1994) or little wheel, derived from the term "rotella" (Diccionario Ilustrado Latin-Español Español-Latín, 1986), that in the oldest Latin also has other meanings, among them "round and thin shield" (Du Cange et al., 1883-1887), which as a formal variant was the most common denomination in Romance languages, but which at the same time is recognized as patella (Terminologia Anatomica) and assimilated in the Castilian with the name of patela. 
Thus, the term patella is derived from late Latin, and was documented by Aulus Cornelius Celso (25 BC $50 \mathrm{AD}$ ) in his book "De Medicina", where he talks about the names of the different body parts (Kachlik et al., 2009). $\mathrm{He}$ is recognized as the greatest authority on anatomical onomatology of his time (Sakai, 2007) and names this bone as patella, which means plate (Mir, 2000) or saucer. While, Valverde in the sixteenth century recognizes it with a round shield form (Valverde de Amufco), with convex face and the other concave, which protects the knee, and not as a wheel. It is also worth noting that in the comments of Berenguer Da Carpi, in 1521, to the Anatomy of Mondino, folio XXXVI and in the margin of the chapter "De Genu", the Latin terms patella and rotula are found. Da Carpi also uses the term "voceusa" as equivalent to patella, which he attributes to Galeno (Bacia Goyanes, 1998).

The term rotula, to designate the sesamoid bone of the knee, is an inadequate term that has been bequeathed to us by the Spaniards and has been perpetuated over time. Fortunately it has been replaced in Terminologia Anatomica by the term patella, which arose even before the term rótula. Therefore, we consider that in Latin America, and particularly in Colombia, the use of those anatomical texts that are edited or translated by Spaniards should be discontinued, since they usually use an outdated anatomical language, saturated with eponymous names and because they do not include international terminology. As the Spanish physician José Celestino Mutis y Bossio asserted toward the end of the 1700 , considered the father of Medicine in Colombia (Palacios Sánchez, 1998), making his position clear in the sense that it was not sensible, or convenient to bring teachers from Spain, since it was more practical and economical to use the staff that were in the viceroyalty to prepare physician and surgeons (CortésGarcía). The present conquest is made by the weight of reason and experimental demonstration, and then agreed upon worldwide.

\section{CONCLUSION}

In agreement with the descriptive study carried out, which shows that in $100 \%$ of the sesamoid bones analyzed none resembles a wheel (rótula), but are rather similar to a plate or to an old shield of defense, by its convex form in the anterior face and concave by its posterior face, we consider that the term "patella", used internationally in the field of morphology and registered in the Terminologia Anatomica with the register A02.5.05.001, is the most appropriate and accepted for the designation of this bone of the knee.
DUQUE, P. J. E.; BARCO, R. J. \& CASTAÑO, M. C. E. Onomatología del término patela: Desde la Antigua Grecia hasta América. Int. J. Morphol., 36(2):758-761, 2018.

RESUMEN: El objetivo de este estudio fue realizar un análisis histórico de los términos "rótula" y "patela" según su onomatología para denominar el hueso sesamoideo en la región anterior de la rodilla, y determinar si corresponde al uso de la terminología anatómica internacional. En el estudio, se seleccionaron 46 huesos sesamoideos bien acondicionados, que se midieron utilizando un calibre digital para determinar su forma geométrica y luego compararlos con los significados dados a lo largo de la historia. Los resultados muestran que las dimensiones obtenidas de estos huesos sesamoideos no corresponden a una forma de ruedecilla (rotula), en su lugar corresponden a una forma cóncava (patela). Esto coincide con el término utilizado en la Terminología Anatómica actual. El término de la rótula para nombrar el hueso sesamoideo en la región anterior de la rodilla esel término más adecuado y aceptado en la terminología anatómica internacional.

PALABRAS CLAVE: Historia; Patela; Terminología.

\section{REFERENCES}

Amezcua Martínez, M. Barberos y sangradores flebotomianos en Granada: norma y sociedad en los siglos XVII y XVIII. Cult. Cuid., 1(1):316, 1997.

Bacia Goyanes, J. J. Un extraño nombre de la rótula: voceusa. Asclepio Arch. Iberoam. Hist. Med. Antropol. Med., 50(1):103-8, 1998.

Cadavid-Restrepo, T. Raíces Griegas y Latinas: Etimologías Médicas y Biológicas. Medellín, Editorial Litografía, 1942.

Cardona, G. R. Antropología de la Escritura. Barcelona, Gedisa, 1994.

Castell, J. V. Norma Castell: Diccionario Enciclopédico. Barcelona, Norma Castell D. L., 1985.

Cortés-García, C. M. Historia de la Medicina en Colombia. De la Medicina ilustrada a la medicina anatomoclínica, 1782-1867. Tomo II. Rev. Gerenc. Polit. Salud, 9(18):157-71, 2010.

Cruveilhier, J. Tratado de Anatomía Descriptiva. Madrid, Bailly-Bailliere, 1851.

Davis, C. R.; Bates, A. S.; Ellis, H. \& Roberts, A. M. Human anatomy: let the students tell us how to teach. Anat. Sci. Educ., 7(4):262-72, 2014.

De las Casas, B. Brevísima Relación de la Destrucción de Las Indias. Madrid, Sarpe, 1985.

De Toro y Gisbert, M. Pequeño Larousse Ilustrado. Buenos Aires, Larousse, 1968.

Diccionario Ilustrado Latin-Español Español-Latín. Barcelona, Bibliograf S. A., 1986.

Du Cange, C. F.; Henschel, G. A. L.; Carpentier, P.; Adelung, J. C. \& Favre, L. Glossarium Mediae et Infimae Latinitatis. Niort, L. Favre, 1883 1887.

Duque Parra, J. E.; Barco Ríos, J. \& Duque Quintero, N. Refining the Anatomical Terminology: Opening and foramen, two similarities and redundancy. Int. J. Morphol., 30(4):1497-9, 2012.

Duque Parra, J. E.; Gomez Arias, N. C. \& Giraldo Ríos, D. P. Nomenclatura anatomica internacional: ¿Un horno microondas en el interior de un volcan activo?. Med. U. P. B., 21(1):43-55, 2002.

Federative Committee on Anatomical Termonology (FIPAT). Terminologia Anatomica. International Anatomical Terminology. Stuttgart, Thieme, 1998. 
Fernández de Oviedo, G. Sumario de la Natural Historia de las Indias. Ciudad de México, Fondo de Cultura Económica, 1996.

García Jáuregui, C. El Léxico del Primer Tratado Anatómico Moderno en Lengua Española (1556). En: Romero Aguilera, L. \& Luna, C. J. (Eds.). Tendencias Actuales en la Investigación Diacrónica de la Lengua. Actas del VII Congreso Nacional de Asociación de Jóvenes Investigadores de Historiografía e Historia de la Lengua Española (AJHILE). Barcelona, Publicacions i Edicions de la Universitat de Barcelona, 2009. pp.301-6.

García Jáuregui, C. Un viaje de ida y vuelta entre la lengua común y la especializada: el léxico anatómico de Juan Valverde de Amusco (1556). Panace@, 7(24):269-74, 2006.

García-Pelayo y Gross, R. Pequeño Larousse en Color. Buenos Aires, Ediciones Larousse, 1993.

García-Porrero, J. A. \& Hurlé, J. M. Anatomía Humana. Madrid, McGrawHill, 2005.

Gersh, C. J. Naming the Body: A Translation with Commentary and Interpretive Essays of Three Anatomical Works Attributed to Rufus of Ephesus. Doctor of Philosophy (Classical Studies) Dissertation. Michigan, Universidad de Michigan, 2012.

Grelsamer, R. P. Patellar nomenclature: the Tower of Babel revisited. Clin. Orthop. Relat. Res., (436):60-5, 2005.

Kachlik, D.; Bozdechova, I.; Cech, P.; Musil, V. \& Baca, V. Mistakes in the usage of anatomical terminology in clinical practice. Biomed. Pap. Med. Fac. Univ. Palacky Olomouc Czech. Repub., 153(2):157-61, 2009.

Mascaró y Porcar, J. M. Diccionario Terminológico de Ciencias Médicas. Barcelona, Salvat Editores S. A., 1983.

Mir, J. M. Diccionario Ilustrado Latino-Español. Barcelona, Publicaciones y Ediciones Spes S. A., 2000.

Moliner, M. Diccionario del Uso del Español. Madrid, Gredos, 1994.

Moore, K. L.; Dailey, A. F. \& Agur, A. M. R. Anatomía con Orientación Clínica. Buenos Aires, WoltersKluver/Lippincott Williams \& Wilkins, 2013.

Palacios Sánchez, L. Algunos aspectos relacionados con José Celestino Mutis y la medicina. Rev. Cienc. Salud, 6(2):99-106, 1998.

Rudgley, R. The Lost Civilizations of the Stone Age. Nueva York, Simon \& Schuster, 2000. pp.48-57.

Sakai, T. Historical evolution of anatomical terminology from ancient to modern.Anat. Sci. Int., 82(2):65-81, 2007.

Schmandt-Besserat, D. Signs of life. Archaeol. Odyssey, 63:6-7, 2002.

Schünke, M.; Schulte, E. \& Schumacher, U. Prometheus Texto y Atlas De Anatomía: Anatomía General y Aparato Locomotor. $2^{\mathrm{a}}$ ed. Buenos Aires: Médica Panamericana, 2011.

Valverde de Amufco, I. Historia de la Composición del Cuerpo Humano. Roma, Impresa por Antonio Salamanca y Antonio Lafrery, 1556.

Yule, G. El Lenguaje. $3^{\mathrm{a}}$ ed. Madrid, Ediciones Akal, 2007.

\author{
Corresponding author: \\ Jorge Eduardo Duque Parra \\ Departamento de Ciencias Básicas \\ Programa de Medicina \\ Universidad de Caldas \\ Calle 9D \# 1C-49 \\ Manizales \\ COLOMBIA
}

E-mail. jorge.duque_p@ucaldas.edu.co

Received: 13-09-2017

Accepted: 17-11-2017 